Article

\title{
Effect of Land Use Change on Soil Carbon Storage over the Last 40 Years in the Shi Yang River Basin, China
}

\author{
Shurong Yang ${ }^{1}{ }^{(\mathbb{D}}$, Danrui Sheng ${ }^{1}$, Jan Adamowski ${ }^{2}$, Yifan Gong ${ }^{1}{ }^{(\mathbb{C}}$, Jian Zhang ${ }^{1}$ \\ and Jianjun Cao ${ }^{1, *}$ \\ 1 College of Geography and Environmental Science, Northwest Normal University, Lanzhou 730070, China; \\ yangsr923@163.com (S.Y.); 18893916226@163.com (D.S.); gongyifan93@163.com (Y.G.); \\ zh_jian06@126.com (J.Z.) \\ 2 Department of Bioresource Engineering, McGill University, Ste Anne de Bellevue, QC H9X 3V9, Canada; \\ jan.adamowski@mcgill.ca \\ * Correspondence: caojj@nwnu.edu.cn; Tel.: +86-138-9361-9610
}

Received: 2 December 2017; Accepted: 16 January 2018; Published: 18 January 2018

\begin{abstract}
Accounting for one quarter of China's land area, the endorheic Shiyang River basin is a vast semi-arid to arid region in China's northwest. Exploring the impact of changes in land use on this arid area's carbon budget under global warming is a key component to global climate change research. Variation in the region's soil carbon storage due to land use changes occurring between 1973 and 2012 was estimated. The results show that land use change has a significant impact on the soil carbon budget, with soil carbon storage having decreased by 3.89 Tg between 1973 and 2012 . Grassland stored the greatest amount of soil carbon $\left(114.34 \mathrm{Mg} \mathrm{ha}^{-1}\right)$, whereas considerably lower carbon storage occurred in woodland ( $\left.58.53 \mathrm{Mg} \mathrm{ha}^{-1}\right)$, cropland $\left(26.75 \mathrm{Mg} \mathrm{ha}^{-1}\right)$ and unused land (13.47 $\mathrm{Mg} \mathrm{ha}^{-1}$ ). Grasslands transformed into cropland, and woodlands degraded into grassland have substantially reduced soil carbon storage, suggesting that measures should be adopted to reverse this trend to improve soil productivity.
\end{abstract}

Keywords: arid area; land use change; soil carbon storage; global carbon balance; the Shiyang River Basin

\section{Introduction}

With soil organic carbon (SOC) representing 2- to 3-fold the carbon pool of vegetation or atmosphere, soil is the terrestrial biosphere's largest carbon sink [1,2]. The SOC is an important factor controlling other soil attributes, which, in turn, are responsible for the sustainable maintenance of soil quality $[3,4]$. Intrinsically related to the productivity of vegetation, the SOC is accordingly very sensitive to natural and human disturbances. Given its enhancement of global climate change, losses of soil carbon to the atmosphere will likely adversely affect food security. Accordingly, reducing SOC losses has become an important strategy in climate change mitigation and food security enhancement [5-7].

Recent studies indicate that climate change is a major driver of shifts in land use and land cover; accordingly, it has a major impact on the global biogeochemical cycle. This is particularly reflected in changing soil carbon storage (SC), net primary productivity, and soil respiration [8,9]. In turn, the impact of shifts in land use on SC further contribute to global warming.

Reflecting the human-land relationship over the long period of human development, alterations in the earth's surface through anthropogenic shifts in land use have become a concern and a topic of research [10]. In 1995, the "Land Use and Land Cover Change" (LUCC) research program, jointly proposed by the International Geosphere-Biosphere Program (IGBP) and International Human 
Dimensions Programme on Global Environmental Change (IHDP), made land-use change a focus of global climate change studies [11]. Studying the impact of land-use change on SC is of particular significance in helping to address climate change on a global scale. Such studies are especially critical for arid and semi-arid regions because these areas are more sensitive to warming and bear little soil moisture, and would thus be more prone to greater SOC decline through faster decomposition [12].

Over the past two decades, many studies [13-16] have focused on the effect of land-use change on the SOC of terrestrial ecosystems at regional or global scales. In China, the impact of land use change on carbon cycling brought on by land management policies has become increasingly apparent in recent years [17-19]. For example, Lü et al. [20] investigated soil carbon storage and water consumption in an oasis-desert ecotone facing land use change. Zhao et al. [21] researched the impact of shifts in land use on SC in an agro-pastoral ecotone of Inner Mongolia. Li et al. [22] estimated the impact of land use change on SOC sequestration in China from 1985 to 2005. However, the effect of shifts in land use on carbon budget in China's arid and semi-arid regions, such as the Shiyang River Basin, has received little attention, which limits our understanding of the mechanisms by which land use change affects the carbon cycle.

Located in the northwest arid and semi-arid region of China, the endorheic Shiyang River Basin is subject to both a high population density and a high level of water resources utilization [23]. Under the region's rapid socioeconomic development land use changes are more constant, and the type of land development and utilization has become more diversified [24]. The process of land use change in this area has resulted in concerns, and many scholars have conducted in-depth studies on the trend of such changes $[24,25]$. However, few studies have focused on the temporal scale of variation in SC caused by land use change. In this paper, our aims are: (i) to explore the long-term effect of shifts in land use on SC; and (ii) to put forward a sustainable land use plan to address a series of environmental issues-especially $\mathrm{CO}_{2}$ emissions-in order to achieve a global carbon balance.

\section{Methods}

\subsection{Study Area}

One of three endorheic river basins in China, the Shiyang River Basin (Figure 1), is located in the eastern portion of the Hexi Corridor $\left(101^{\circ} 22^{\prime}-104^{\circ} 04^{\prime} \mathrm{E}, 37^{\circ} 07^{\prime}-39^{\circ} 27^{\prime} \mathrm{N}\right)$, covers an area of about $41.6 \times 10^{3} \mathrm{~km}^{2}$ and is home to 2.3 million people. Receiving inputs from eight tributaries, the $300 \mathrm{~km}$ long Shiyang River has a yield area of $11.1 \times 10^{3} \mathrm{~km}^{2}$ and a mean annual runoff volume of $1.56 \times 10^{9} \mathrm{~m}^{3}$. The river's middle and lower reaches are characterized by a temperate continental climate, with an annual mean temperature of $7.7^{\circ} \mathrm{C}$, and mean annually cumulated precipitation and evaporation of 115-158 $\mathrm{mm} \mathrm{y}^{-1}$ and $1963-2637 \mathrm{~mm} \mathrm{y}^{-1}$, respectively. Soils in this area (soils in this area were classified according to the Chinese soil type designations) can be classified into gray-brown desert, saline and meadow soils (on the banks of rivers and lakes), and non-zonal wind sand soil (oases and the edge of the Gobi Desert). 


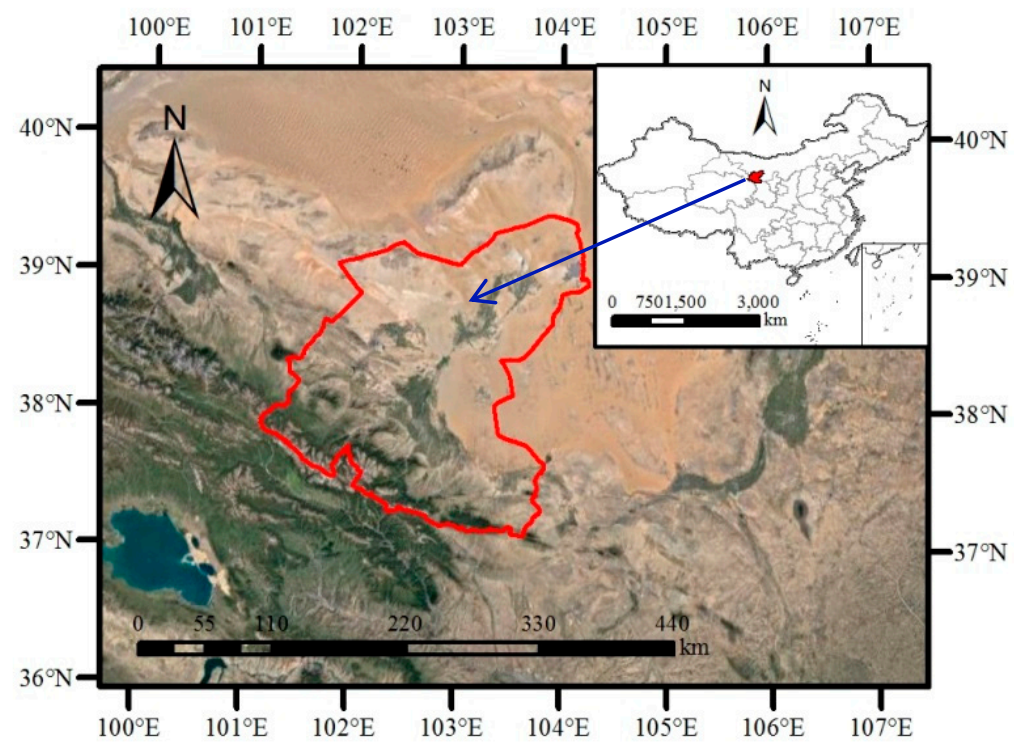

Figure 1. The geographic location of the Shiyang River Basin in China.

\subsection{Data Sources}

Data regarding the Shiyang River Basin land use changes from 1973 to 2008 was drawn from Jia et al. [25], while data on 2008 to 2012 changes was drawn from Sun et al. [26]. Both previous studies were based on remote sensing technology drawing on Landsat imagery.

According to the characteristics of mountain-oases-desert in the study area, land use in the study area was categorized into seven types: (i) cropland; (ii) woodland; (iii) grassland; (iv) water, i.e., rivers, reservoirs and ponds; (v) urban land; (vi) unused land, such as desert, Gobi and naked land; (vii) glaciers and permanent snow.

\subsection{Research Methods}

Soil carbon storage was calculated as [27]:

$$
\mathrm{SC}=\mathrm{SOC} \times \rho \times \mathrm{T} \times \mathrm{S}
$$

where $\mathrm{SC}$ is the total soil organic carbon storage $(\mathrm{Mg}), \mathrm{SOC}$ is soil organic carbon content across a given soil depth (\%), in this case $20 \mathrm{~cm}, \mathrm{~S}$ is the area of a given land use $\left(\mathrm{km}^{2}\right)$, T refers to the depth to which SC is calculated $(\mathrm{cm})$, and $\rho$ is soil bulk density $\left(\mathrm{g} \mathrm{cm}^{-3}\right)$.

Values of soil bulk density of grassland, cropland, and unused land were drawn from Zhou et al. [28], Yu et al. [29], and Li et al. [30], respectively, while the values of $\rho$ for woodland came from sand-fixing forest soil in Minqin Oasis [31]. Values of soil organic matter were drawn from Zhou et al. [28], Wang et al. [31], Yu et al. [29], Li et al. [30], and Yang et al. [32].

Soil organic matter (SOM) bears roughly $58 \%$ (the "van Bemmelen factor") carbon [33]; accordingly, on a gravimetric basis:

$$
\mathrm{SOM}=1.724 \times \mathrm{SOC}
$$

\section{Results}

\subsection{Land Use Change in the Shiyang River Basin}

Based on Jia et al. [25] and Sun et al. [26], shifts in land use varied in different periods over the last 40 years, but in general, croplands, urban lands, and glacier and permanent snow-covered lands increased (Figure 2). The more than doubling of cropland acreage from 1973 to 2008, resulted in the areal proportion of cropland rising from $7.07 \%$ in 1973 to $20.06 \%$ in $2012\left(+0.325 \% \mathrm{y}^{-1}\right)$. 
The proportion of urban land more than doubled over the same period: from $0.15 \%$ in 1973 to $0.37 \%$ in $2012\left(+0.0055 \% \mathrm{y}^{-1}\right)$ augmentation. Meanwhile the area of glaciers and permanent snow cover increased slowly (Figure 2a). However, the area of woodlands, grasslands, water bodies and unused lands declined. Grasslands and woodlands showed the greatest decrease in area, $743.6 \mathrm{~km}^{2}$ for the former, and $460.73 \mathrm{~km}^{2}$ for the latter. From 1973 to 1987, the area of woodlands declined by $608.21 \mathrm{~km}^{2}$, but subsequently increased after 1994. Before 1987, the area of water bodies increased, and then decreased sharply from 1987 to 1994, their decline then slowing down. Although the area of unused lands also decreased, it still accounted for $80.0 \%$ of the total land area (Figure $2 b$ ).
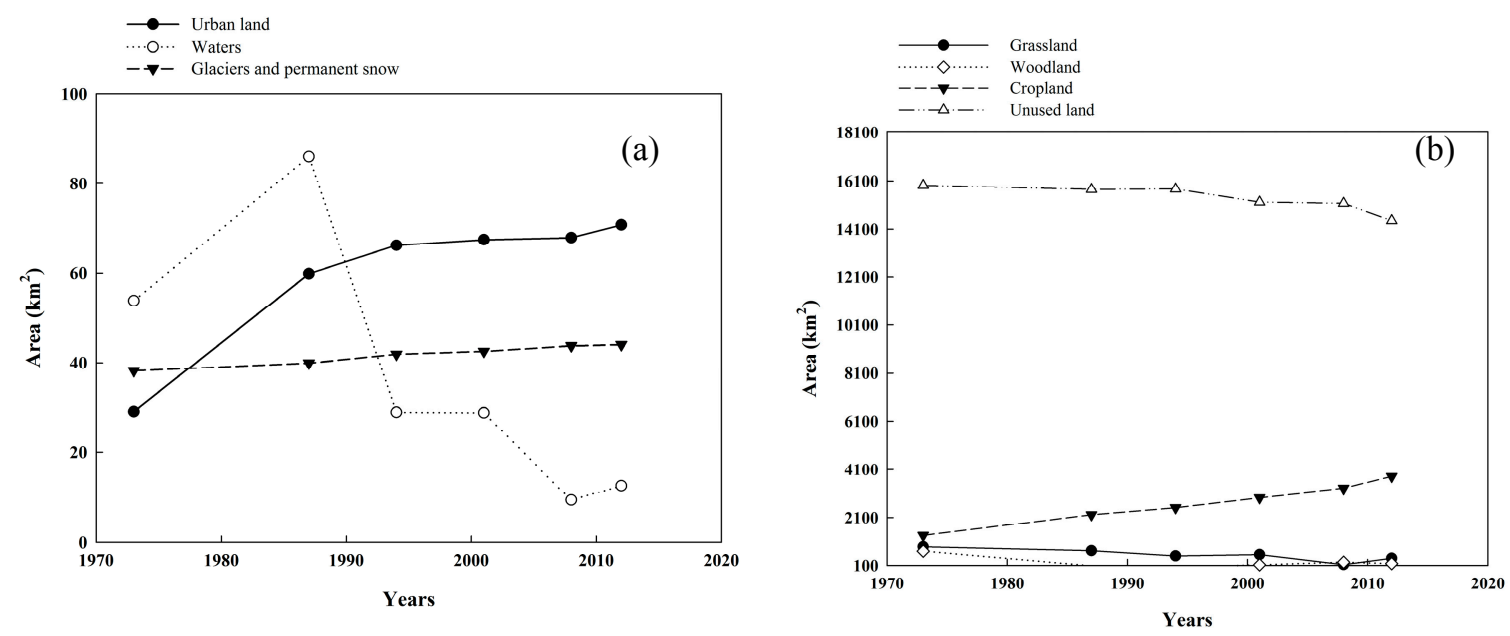

Figure 2. The area of urban land, waters, glaciers and permanent snow (a) and grassland, woodland, cropland, and unused land (b) in 1973, 1987, 1994, 2001, 2008 and 2012, respectively.

Due to the influence of human activities and economic development in the Shiyang River Basin over the period of 1973 to $2008,659.55 \mathrm{~km}^{2}$ of grasslands were converted to cropland, while $455.65 \mathrm{~km}^{2}$ degraded into unused land. Meanwhile, $267.46 \mathrm{~km}^{2}$ of woodlands degraded into grassland during the same period [25] (Figure 2b).

\subsection{The Change of Soil Carbon Storage in the Shiyang River Basin}

As the four land uses of grasslands, woodlands, croplands and unused lands accounted for more than $90 \%$ of the land area in the Shiyang River Basin, the present study focused on these land uses. Overall, the total SC (Equation (1)) first declined, then increased. From 1973 to 2012, the SC decreased by $3.89 \mathrm{Tg}$. The SC under different land uses was ranked in the order: unused land > cropland > grassland $>$ woodland (Table 1 ).

Table 1. Soil carbon storage in the Shiyang River Basin from 1973 to 2012.

\begin{tabular}{|c|c|c|c|c|c|c|c|c|c|c|}
\hline \multirow{2}{*}{ Land Cover Types } & \multirow{2}{*}{ SOC (\%) } & \multirow{2}{*}{$\rho\left(\mathrm{g} \mathrm{cm}^{-3}\right)$} & \multirow{2}{*}{$\mathrm{T}(\mathrm{cm})$} & \multirow{2}{*}{$\mathrm{SC}\left(\mathrm{Mg} \mathrm{ha}^{-1}\right)$} & \multicolumn{6}{|c|}{ Soil Carbon Storage (Tg) } \\
\hline & & & & & 1973 & 1987 & 1994 & 2001 & 2008 & 2012 \\
\hline Grassland & $5.15 \mathrm{a}$ & 1.11 & 20 & 114.34 & 10.01 & 8.15 & 5.67 & 6.29 & 1.51 & 4.55 \\
\hline Woodland & $2.15 \mathrm{a}$ & 1.36 & 20 & 58.53 & 4.06 & 0.50 & 0.24 & 0.71 & 1.36 & 1.02 \\
\hline Cropland & $0.85 \mathrm{~b}$ & 1.57 & 20 & 26.75 & 3.59 & 5.92 & 6.71 & 7.83 & 8.84 & 10.17 \\
\hline Unused land & $0.45 \mathrm{~b}$ & 1.51 & 20 & 13.47 & 21.44 & 21.22 & 21.24 & 20.49 & 20.42 & 19.46 \\
\hline Total & - & - & - & - & 39.09 & 35.79 & 33.87 & 35.32 & 32.13 & 35.20 \\
\hline
\end{tabular}

Note: Different lower-case letters show differences at $p<0.05$ level. 


\section{Discussion}

\subsection{Reasons for Land Use Change in the Shiyang River Basin in the Last 40 Years}

From 1973 to 2012, the expanse of unused lands changed slowly as these lands were of little economic value; however, the small reduction their area in recent years reflect a rising intensity in the development and utilization of oases within the basin [25]. From 1973 to 2008, following China's 1978 reforms, the Shiyang River Basin's agrarian population increased rapidly, and the region's economic development proceeded apace. This stimulated the demand for land, ultimately resulting in grasslands, unused lands, and waters being converted to croplands and urban areas, thereby increasing overall water consumption. With excessive exploitation of groundwater resources and land resources, land desertification occurred, and the area of abandoned/unused lands increased [25,34]. In response, an afforestation policy was implemented by central and local governments in 1994, to achieve regional sustainability.

After 1994, the area of woodlands accordingly increased. The population increased slowly too, suggesting that the implemented policies were succeeding in resolving regional sustainability issues, and that urban expansion had leveled off. However, in these arid areas, changes in land use or land cover can affect soil moisture, leading to fluctuations in groundwater tables [35,36]. Although the effect on soil water of land use changes brought on by afforestation have yet to be investigated within the Shiyang River Basin, many studies in other similar regions (e.g., Nosetto et al. [37]; Cao et al. [38]; Cao and Zhang [39]; Peng et al. [40]) have suggested that afforestation can worsen water resource shortages. The higher leaf area index and lower albedo of forested lands allow a greater absorption of solar radiation at the earth's surface and therefore greater evapotranspiration, while trees' deeper roots provide better access to deep water resources, raising soil water consumption [40,41]. Besides unrestricted and wasteful irrigation during the period of 2001 to 2008, afforestation may have also contributed to the reduction in area of water bodies. However, after 2008, this trend was reversed, mainly due to a change in irrigation practices from flood irrigation to drip irrigation, while well irrigation was prohibited.

\subsection{The Effect of Land Use Change on Soil Carbon Storage in Shiyang River Basin}

According to Yang et al. [32], the SOM in Shiyang River Basin grasslands and woodlands was over 2.5-fold that of croplands. However, in the present study, SOC in grasslands was 6 times that in croplands, and SOC in woodlands was 2.5 times that in croplands. Grasslands and woodlands stored more SOC than croplands, because grasslands and woodlands generated more plant litter residue than croplands, and a larger proportion of it was returned to the soil. Plants and animal residues can provide a good carbon source for microbial activity after entering the soil. Microbial activity is conducive to carbon fixation from the atmosphere, thereby gradually increasing SOM content $[42,43]$. Unused lands were mostly barren and their surface had long been exposed; accordingly, their soils' SOM content was low compared to other land uses [32].

From 1973 to 1994, the net increment in total SC in the Shiyang River Basin was negative, brought on by shifts in land use from woodlands to cropland, and from grasslands to cropland. As the implementation of the government afforestation policy limited the expansion of cropland, the total SC increased slightly during the period of 1994 to 2001 [25]. Over the period of 2001 to 2008 , total SC in grasslands decreased drastically, largely due to the poor management of these lands leading to their degradation and carbon release [44,45]. Ge et al. [46], operating in China's Xinjiang region, similarly found that shifts in land uses from grasslands to cropland, as well as from woodlands to grassland reduced the SC. In the Shiyang River Basin, the 2008 implementation of a vigorous cropland to grassland conversion project along with a reforestation project, linked to a comprehensive watershed treatment project, resulted in an increase in soil fertility and SC throughout the whole basin [32]. The total SC of woodlands decreased significantly, because a large area of woodlands degenerated into grasslands. The total SC of croplands has been increasing due to the application 
of organic fertilizers in recent years, but the total SC of unused lands has been declining due to urbanization and continuous population growth.

4.3. Comparison of Soil Carbon Storage in Shiyang River Basin with Similar Ecosystems in Other Regions of the World

Comparing SC in the Shiyang River Basin with that in similar ecosystems around the world, total SC in the Shiyang River basin was found to be slightly lower than in the Sangong River watershed, but higher than that in Botswana Kalahari and Tigray regions. Both the SOC and SC showed the same trends (Table 2). However, present global SC stocks show a declining trend in all regions due to climate change and shifting land use practices $[47,48]$.

Table 2. Soil carbon storage in the Shiyang River Basin compared to other sites worldwide.

\begin{tabular}{cccc}
\hline Region & SC $\mathbf{( M g ~ h a} \mathbf{~ h}^{-\mathbf{1}} \mathbf{)}$ & SOC (\%) & Reference \\
\hline Kalahari desert (Botswana) & 13.97 & 0.13 & {$[47]$} \\
Tigray (Northern Ethiopia) & 31.60 & - & {$[48]$} \\
Sangong River watershed & 67.00 & 3.43 & {$[49]$} \\
Shiyang River Basin & 53.27 & 2.15 & This Study \\
\hline
\end{tabular}

As climate change and shifts in land use proceed, soil carbon pools may become "sources" of atmospheric $\mathrm{CO}_{2}$. For example, it was estimated that release of carbon to the atmosphere due to these reasons from the world's soils are at $40-50 \mathrm{Pg} \mathrm{C} \mathrm{y}^{-1}$, and over the last 150 years, the decline of soil organic carbon has contributed $6-8 \%$ of the rise in atmospheric $\mathrm{CO}_{2}$ [50]. Carbon loss is not only driven by change in land cover, but also could be driven by change in land management as confirmed by Cao et al. [45]. In their study, they found that $0.41 \mathrm{Mg} \mathrm{C} \mathrm{ha}^{-1} \mathrm{y}^{-1}$ has been lost on the Qinghai-Tibetan Plateau under the single-household (land) management pattern where grassland is enclosed and only used by a single household, compared with multi-household (land) management where grassland is not enclosed and commonly used by these households [45]. If we consider carbon loss caused by change in land management in the Shiyang River basin, carbon loss would be larger, but this needs further study. The increase or decrease of soil organic carbon storage is related to soil quality, and thus continued carbon loss from soil will reduce or destroy, at a local scale, the productivity of land, and the greenhouse effect will be intensified on a global scale.

\section{Conclusions}

Land use changes in the Shiyang River basin over the last 40 years were mainly restricted to croplands, grasslands and woodlands. Cropland, urban, and glacier/permanent snow cover areas all increased in relative area, whereas woodlands, grasslands, water bodies and unused lands declined.

Driven by natural and human activities, shifts in land use in this region have had a significant impact on the carbon balance and sustainable development. Overall, the land use changes have resulted in a $3.89 \mathrm{Tg}$ decrease in total soil carbon storage from 1973 to 2012 in the basin.

In order to maintain the functional stability of the soil carbon pool in this region, measures that could improve soil productivity and reduce the emission of greenhouse gases such as $\mathrm{CO}_{2}$ should be adopted [51]. These should include local governments organizing the development of long-term land use strategies, providing scientific guidance to people in the area, promoting and providing instruction in advanced farming techniques, as well as enhancing people's awareness of environmental protection. 
Acknowledgments: This study was supported by the National Natural Science Foundation of China (41461109, 41461012), the Gansu Provincial Sci \& Tech. Department (1506RJZA124), and Key Laboratory of Ecohydrology of Inland River Basin, Chinese Academy of Science (KLEIRB-ZS-16-01).

Author Contributions: The main part of this study was performed by Shurong Yang, Danrui Sheng and Jianjun Cao, while the other authors were involved in advising, writing and revising.

Conflicts of Interest: The authors declare no conflict of interest.

\section{References}

1. Batijes, N.H. Total carbon and nitrogen in soils of the world. Eur. J. Soil Sci. 1996, 47, 151-163. [CrossRef]

2. Maraseni, T.; Pandey, T. Can vegetation types work as an indicator of soil organic carbon? An insight from native vegetations in Nepal. Ecol. Indic. 2014, 46, 315-322. [CrossRef]

3. Gregory, A.S.; Watts, C.W.; Griffiths, B.S.; Hallett, P.D.; Kuan, H.L.; Whitmore, A.P. The effect of long-term soil management on the physical and biological resilience of a range of arable and grassland soils in England. Geoderma 2009, 153, 172-185. [CrossRef]

4. Hazarika, S.; Thakuria, D.; Ganeshamurthy, A.N.; Sakthivel, T. Soil quality as influenced by land use history of orchards in humid subtropics. Catena 2014, 123, 37-44. [CrossRef]

5. Shrestha, H.L.; Bhandari, T.S.; Karky, B.S.; Kotru, R. Soil properties linking to climate change mitigation and food security in Nepal. Environments 2017, 4, 29. [CrossRef]

6. Bruun, T.B.; Elberling, B.; Neergaard, A.D.; Magid, J. Organic carbon dynamics in different soil types after conversion of forest to agriculture. Land Degrad. Dev. 2015, 26, 272-283. [CrossRef]

7. Keesstra, S.D.; Bouma, J.; Wallinga, J.; Tittonell, P.; Smith, P.; Cerdà, A.; Montanarella, L.; Quinton, J.N.; Pachepsky, Y.; Van der Putten, W.H.; et al. The significance of soils and soil science towards realization of the United Nations Sustainable Development Goals. Soil 2016, 2, 111-128. [CrossRef]

8. Dintwe, K.; Okin, G.S. Soil organic carbon in savannas decreases with anthropogenic climate change. Geoderma 2018, 309, 7-16. [CrossRef]

9. Chuluun, T.; Ojima, D. Land use change and carbon cycle in arid and semi-arid lands of East and Central Asia. Sci. China Ser. C 2002, 45, 48-54.

10. Zhang, J.M. Land Use/Land Cover Change and Its Environmental Effects in Shiyang River Basin; Lanzhou University: Lanzhou, China, 2007. (In Chinese)

11. Jiang, P.H.; Zhao, R.F.; Zhao, H.L.; Fan, J.P.; Wang, J.Z.; Liu, C. Spatial-temporal evolution of land use/cover change in middle section of Heihe Basin since 1975. J. Ecol. Rural Environ. 2012, 28, 473-479. (In Chinese)

12. Buytaert, W.; Deckers, J.; Wyseure, G. Regional variability of volcanic ash soils in south Ecuador: The relation with parent material, climate and land use. Catena 2007, 70, 143-154. [CrossRef]

13. Lozano-García, B.; Parras-Alcántara, L.; Cantudo-Pérez, M. Land use change effects on stratification and storage of soil carbon and nitrogen: Application to a Mediterranean nature reserve. Agric. Ecosyst. Environ. 2016, 231, 105-113. [CrossRef]

14. Sá, J.C.D.M.; Séguy, L.; Tivet, F.; Lal, R.; Bouzinac, S.; Borszowskei, P.R.; Briedis, C.; Santos, J.B.D.; Hartman, D.D.C.; Bertoloni, C.G.; et al. Carbon depletion by plowing and its restoration by no-till cropping systems in Oxisols of subtropical and tropical Agro-Ecoregions in Brazil. Land Degrad. Dev. 2015, 26, 531-543. [CrossRef]

15. Montiel-Rozas, M.D.M.; Panettieri, M.; Madejón, P.; Madejón, E. Carbon sequestration in restored soils by applying organic Amendments. Land Degrad. Dev. 2016, 27, 620-629. [CrossRef]

16. Willaarts, B.A.; Oyonarte, C.; Muñoz-Rojas, M.; Ibáñez, J.J.; Aguilera, P.A. Environmental factors controlling soil organic carbon stocks in two contrasting Mediterranean climatic areas of Southern Spain. Land Degrad. Dev. 2016, 27, 603-611. [CrossRef]

17. Zhang, Y.L.; Cai, X.J.; Lv, J.L. Size and dynamics of soil organic carbon stock in cropland of the Eastern Qinghai-Tibetan Plateau. Agric. Ecosyst. Environ. 2016, 222, 125-132. [CrossRef]

18. Wang, S.P.; Wilkes, A.; Zhang, Z.C.; Chang, X.F.; Lang, R.; Wang, Y.F.; Niu, H.S. Management and land use change effects on soil carbon in northern China's grasslands: A synthesis. Agric. Ecosyst. Environ. 2011, 142, 329-340. [CrossRef]

19. Deng, L.; Liu, G.B.; Shangguan, Z.P. Land-use conversion and changing soil carbon stocks in China's 'Grain-for-Green' Program: A synthesis. Glob. Chang. Biol. 2014, 20, 3544-3556. [CrossRef] [PubMed] 
20. Lü, Y.; Ma, Z.; Zhao, Z.; Sun, F.; Fu, B. Effects of land use change on soil carbon storage and water consumption in an Oasis-Desert Ecotone. Environ. Manag. 2014, 53, 1066-1076. [CrossRef] [PubMed]

21. Zhao, W.; Hu, Z.M.; Li, S.G.; Guo, Q.; Yang, H.; Zhang, T.H. Impact of land use conversion on soil organic carbon stocks in an agro-pastoral ecotone of inner Mongolia. J. Geogr. Sci. 2017, 27, 999-1010. [CrossRef]

22. Li, M.; Wu, J.; Deng, X. Land use change and soil carbon sequestration in China: Where does it pay to conserve? Reg. Environ. Chang. 2016, 16, 2429-2441. [CrossRef]

23. Zhou, J.X.; Liu, S.Y.; Wang, P. Analysis of time differentiation of land use dynamic degree in Liangzhou district of Wuwei city. Guizhou Agric. Sci. 2011, 39, 218-221. (In Chinese)

24. Shang, H.Y.; Zhang, Z.Q. Analysis on effect of land-use types and change of Shiyang River Basin. Resour. Dev. Mark. 2015, 31, 40-43. (In Chinese)

25. Jia, Y.; Yan, L.; Yu, F.; Cao, L.L. Land use change and landscape pattern of typical semi-arid and arid watershed of western China: A case study on Shiyang River Basin. Remote Sens. Inf. 2016, 31, 66-73. (In Chinese)

26. Sun, D.Y.; Jin, Y.Z.; Chai, W.W.; Hu, X.Q.; Lu, S.C.; Song, Z.F.; Zeng, J.J. Fractal characteristics of land use change in Shiyang River Basin. Chin. Agric. Sci. Bull. 2016, 32, 80-87. (In Chinese)

27. Shang, Z.H.; Cao, J.J.; Guo, R.Y.; Long, R.J.; Deng, B. The response of soil organic carbon and nitrogen 10 years after returning cultivated alpine steppe to grassland by abandonment or reseeding. Catena 2014, 119, 28-35. [CrossRef]

28. Zhou, L.; Zhang, D.G.; Yun, X.J.; Dong, Y.P.; Wang, J.T.; Zhao, Y.L. The vegetation and soil characteristics of degraded alpine meadow. Pratac. Sci. 2016, 33, 2196-2201. (In Chinese)

29. Yu, H.L.; Zhang, E.H.; Wang, Q.; Liu, Q.L.; Liu, C.W.; Wang, T.T.; Yin, H. Effects of irrigation and N supply levels on soil organic carbon, total nitrogen and grain yield of spring wheat on no-tillage Farmland with standing stubble. Acta Pratac. Sin. 2013, 22, 227-233. (In Chinese)

30. Li, Y.K.; Liu, S.Z.; Liu, H.J.; Wei, H.D.; Yang, Z.H.; Zhang, Y.H.; Liu, S.J. Study on soil characteristics of desert-riverside ecotone in middle and lower reaches of Shiyang River. Res. Soil Water Conserv. 2012, 19, 29-35. (In Chinese)

31. Wang, Y.W.; Ouyang, X.Z.; Luo, L.; Zhang, F.; Gao, J.F. Spatial-temporal variation of the physicochemical properties of sand-fixing forest soil in Minqin Oasis. Yellow River 2017, 39, 85-89. (In Chinese)

32. Yang, W.Z.; Wei, C.; Lian, B.; Dai, C.Y.; Chen, N.L. Soil fertility characteristics under different land-use patterns in Shiyanghe Basin. J. Gansu Agric. Univ. 2011, 46, 112-117. (In Chinese)

33. Pribyl, D.W. A critical review of the conventional SOC to SOM conversion factor. Geoderma 2010, 156, 75-83. [CrossRef]

34. Zhou, J.J.; Lei, L.; Shi, P.J.; Wang, L.Y.; Wei, W.; Liu, H.M. Response of runoff to the climate and land use pattern changes in Shiyang River Basin. Acta Ecol. Sin. 2015, 35, 3788-3796. (In Chinese)

35. Trabucco, A.; Zomer, R.J.; Bossio, D.A.; Straaten, O.V.; Verchot, L.V. Climate change mitigation through afforestation/reforestation: A global analysis of hydrologic impacts with four case studies. Agric. Ecosyst. Environ. 2008, 126, 81-97. [CrossRef]

36. Jia, X.; Shao, M.; Zhu, Y.; Luo, Y. Soil moisture decline due to afforestation across the loess plateau, China. J. Hydrol. 2017, 546, 113-122. [CrossRef]

37. Nosetto, M.D.; Jobbágy, E.G.; Paruelo, J.M. Land-use change and water losses: The case of grassland afforestation across a soil textural gradient in central Argentina. Glob. Chang. Biol. 2005, 11, 1101-1117. [CrossRef]

38. Cao, S.; Chen, L.; Shankman, D.; Wang, C.; Wang, X.; Zhang, H. Excessive reliance on afforestation in China's arid and semi-arid regions: Lessons in ecological restoration. Earth Sci. Rev. 2011, 104, 240-245. [CrossRef]

39. Cao, S.; Zhang, J. Political risks arising from the impacts of large-scale afforestation on water resources of the Tibetan Plateau. Gondwana Res. 2015, 28, 898-903. [CrossRef]

40. Peng, S.S.; Piao, S.L.; Zeng, Z.Z.; Ciais, P.; Zhou, L.M.; Li, L.Z.; Myneni, R.B.; Yin, Y.; Zeng, H. Afforestation in China cools local land surface temperature. Proc. Natl. Acad. Sci. USA 2014, 111, 2915-2919. [CrossRef] [PubMed]

41. Calder, I.R. Water use of eucalypts-A review with special reference to South India. Agric. Water Manag. 1986, 11, 333-342. [CrossRef]

42. Wang, Q.K.; Wang, S.L.; Feng, Z.W.; Huang, Y. Active soil organic matter and its relationship with soil quality. Acta Ecol. Sin. 2005, 25, 513-519. (In Chinese) 
43. Zhao, J.H.; Gao, C.; Zhang, D.L. Study on the soil organic carbon density of alpine meadow with different degradation degrees in eastern Qilian Mountains. Acta Agrestia Sin. 2010, 18, 21-25. (In Chinese)

44. Cao, J.J.; Yeh, E.T.; Holden, N.M.; Yang, Y.Y.; Du, G.Z. The effects of enclosures and land-use contracts on rangeland degradation on the Qinghai-Tibetan Plateau. J. Arid Environ. 2013, 97, 3-8. [CrossRef]

45. Cao, J.J.; Gong, Y.F.; Holden, N.M.; Zhang, J.; Zhang, S.H.; Yang, S.R.; Xu, X.Y.; Li, M.T.; Feng, Q. Impact of grassland contract policy on soil organic carbon losses from alpine grassland on the Qinghai-Tibetan Plateau. Soil Use Manag. 2017, 33, 663-671. [CrossRef]

46. Ge, Q.S.; Dai, J.H.; He, F.N.; Pang, Y.; Wang, M.M. Study on land use/land cover change and carbon cycle in China over the past 300 years. Sci. China Press D Geosci. 2008, 38, 197-210. (In Chinese)

47. Dintwe, K.; Okin, G.S.; D'Odorico, P.; Hrast, T.; Mladenov, N.; Handorean, A.; Bhattachan, A.; Caylor, K.K. Soil organic $\mathrm{C}$ and total $\mathrm{N}$ pools in the Kalahari: Potential impacts of climate change on $\mathrm{C}$ sequestration in savannas. Plant Soil 2014, 396, 27-44. [CrossRef]

48. Gelaw, A.M.; Singh, B.R.; Lal, R. Soil organic carbon and total nitrogen stocks under different land uses in a semi-arid watershed in Tigray, Northern Ethiopia. Agric. Ecosyst. Environ. 2014, 188, 256-263. [CrossRef]

49. Xu, W.Q.; Chen, X.; Luo, G.P.; Wang, T.; Lin, Q. Soil organic carbon storage and its spatial distribution characteristic in the Sangong River Watershed of arid region. J. Nat. Resour. 2009, 24, 1740-1747. (In Chinese)

50. Mullen, R.W.; Thomason, W.E.; Rawn, W.R. Estimated increase in atmospheric carbon dioxide due to worldwide decrease in soil organic matter. Commun. Soil Sci. Plant Anal. 1999, 30, 1713-1719. [CrossRef]

51. Yang, Y.H.; Chen, Y.N.; Li, W.H.; Wang, Y. Effects of land use/cover change on soil organic carbon storage in the main stream of Tarim River. China Environ. Sci. 2016, 36, 2784-2790. (In Chinese)

(C) 2018 by the authors. Licensee MDPI, Basel, Switzerland. This article is an open access article distributed under the terms and conditions of the Creative Commons Attribution (CC BY) license (http://creativecommons.org/licenses/by/4.0/). 